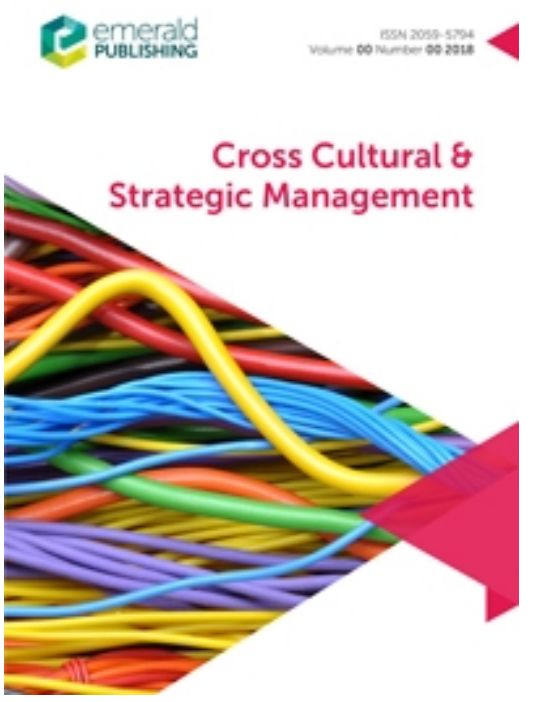

\title{
Being different matters! A closer look into product differentiation in specialty coffee family farms in Central America.
}

\begin{tabular}{|r|l|}
\hline Journal: & Cross Cultural \& Strategic Management \\
\hline Manuscript ID & CCSM-01-2019-0004.R4 \\
\hline Manuscript Type: & Research Paper \\
\hline Keywords: & $\begin{array}{l}\text { Family Business, Strategy, differentiation, stewardship, Central America, } \\
\text { coffee }\end{array}$ \\
\hline \multicolumn{2}{l}{} \\
\hline
\end{tabular}

\section{SCHOLARONE ${ }^{m}$ Manuscripts}




\title{
Being different matters! A closer look into product differentiation in specialty coffee family farms in Central America.
}

\begin{abstract}
Purpose - There is a growing interest in understanding the strategic behaviour of family firms producing international commodities such as coffee, particularly in contexts where decisions about what products to sell, where to commercialise them, and how to promote them appears to be highly based on both business and family aspects. The purpose of this paper is to explore product differentiation strategies in family firms in the specialty coffee industry across Latin American countries. Whilst the socioeconomic relevance of coffee production in Central America is unequivocal, the approach and rationale of families that engage in specialty coffee production remains underexplored.
\end{abstract}

Design/methodology/approach - This study examines product differentiation in specialty coffee family farms across countries in Central America: Guatemala, Honduras, and Nicaragua. The study relies on in-depth interviews, case studies, and an interpretative approach to unpick the dynamics of product differentiation by families in business dedicated to producing specialty coffee.

Findings - The findings show that product differentiation in specialty coffee family farms is influenced by both business and family aspects and driven by entrepreneurial stewards. Coffee farming families can engage in product differentiation through a shared vision, a combination of traditional and specialised knowledge, and through the continuous development of an exchange network. The findings reveal a connection between families in business balancing family and business interests, and the strategic intention to build up their assets entrepreneurially over time.

Originality/value - This study contributes to the literature on stewardship and strategic behaviour in family firms when families in business engage in differentiating their products in a highly competitive industry. More specifically, this study focuses on companies across countries where coffee is of crucial socioeconomic importance, and where the said companies are owned and managed by families. The study expands understanding of product differentiation in familyenterprise-first businesses and suggests that the family elements in differentiation can be explained through an entrepreneurial stewardship perspective. 
Keywords: Family business, strategy, differentiation, stewardship, Central America, coffee.

\section{Introduction}

In 2018, the world consumed 165 million sacks of coffee, an increase of $2.1 \%$ from the previous year, and there are expectations that this will rise further in the future (ICO, 2019). Rough statistics from the International Coffee Organisation (ICO) indicate that approximately three billion cups of coffee are consumed every day around the world, with North America, Europe, and Japan accounting for almost 53\% of coffee consumption. In the US alone, the retail value of the coffee market reached US\$87-88 billion in 2018, with coffee houses continuing to be a significant place of consumption outside the home (SCAA, 2019). Coffee is a long-standing, internationally traded, agricultural commodity worthy of attention because of increasing levels of competition, varying customer demands and product saturation (Bacon, 2008; Ponte, 2002; Rueda and Lambin, 2013). Still, whilst the increasing sophistication of the coffee industry has pushed producers worldwide to find ways to transform their product into a differentiated, added value offering (Ponte, 2002; Reinecke et al., 2012), there is little understanding about how and why coffee-producing firms differentiate their products. As the history of the coffee industry around the world has been long associated with - and dominated by - family businesses (Pendergrast, 2010), then their approach to product differentiation merits further attention.

This study is motivated by the need to understand the approach and rationale behind product differentiation strategies in family businesses that engage in specialty coffee production. Such a pursuit is important, as recent studies suggest that family businesses may engage in diverse strategies in order to compete (Basco, 2014). Discerning how and why a differentiation strategy emerges in family business is valuable, as such an undertaking is positioned as the sine qua non to achieve long-term competitiveness in increasingly challenging environments. Family business strategies, such as product differentiation, may be only understandable within the specific context and place in which they occur, as they reflect unique dynamics where family members interact with diverse actors across time (Roscoe et al., 2013). To advance understanding, this study focuses on the approach and rationale behind a product differentiation strategy in family firms producing specialty coffee.

In the coffee industry, product differentiation can be achieved by highlighting special features linked to a place of origin (Teuber, 2010; Mizumoto, 2009). Yet, the increasing association of family dynamics with strategies in the farming sector cannot be underestimated (Fitz-Koch et al., 2019). The influence of family in product differentiation may be more relevant 
than previously believed. Recent studies suggest that families may engage in product differentiation within existing firms through common understandings, resources, and relationships (Discua Cruz et al., 2013). Yet there is no empirical evidence as to how and why it occurs in family businesses across countries that produce and commercialise coffee. Thus, this study aims to answer the following questions: How and why do family businesses in the coffee industry engage in product differentiation? To what extent does family influence product differentiation in the coffee industry?

To answer our questions, this study focuses on cases from Guatemala, Honduras, and Nicaragua, where coffee plays a vital socioeconomic role (Paz Cafferata and Pomareda, 2009) and family businesses dominate (Fernández Pérez and Lluch, 2016; Müller et al., 2019). Such a context is relevant as some farming families, when facing diverse contextual pressures, may opt to exit the coffee industry, while others may differentiate their products (Vega Solano \& Discua Cruz, 2017). To contribute to the understanding of this subject, this study draws on the underlying premises of product differentiation strategies, strategic behaviour (Basco, 2014), and entrepreneurial stewardship in family firms (Discua Cruz et al., 2013). Based on the narratives of families in business (Hamilton et al., 2017) that produce specialty coffee, we extend understanding of the motivation and rationale behind a differentiation strategy in family businesses.

The findings reveal that coffee farming families can construct a differentiated product by: creating a shared family vision and collective commitment to remain in business together; leveraging and combining existing and newly-acquired resources; and shaping the creation and development of a business network. Taken together, the findings extend understanding of family-enterprise-first firms and suggest that in coffee family businesses, product differentiation may be shaped over time by entrepreneurial stewards who build and leverage family assets and relational resources.

The paper continues as follows: It first describes the theoretical background, then it explains the contextual dimensions in the coffee industry and the research method. It follows up by focusing on case findings and discussion. Finally, it suggests limitations and opportunities for further research.

\section{Theoretical Framework}

A focus on family businesses 
Using an appropriate definition provides a starting point from which to theorise about family businesses and differentiation strategies. Family business researchers agree that the intertwinement between family and business is what defines a family firm (Melin et al., 2014). Such intertwinement differentiates family businesses from non-family counterparts in the long term, makes every family business unique, and has consequences in creating an idiosyncratic bundle of resources resulting from the interaction of family and business, known as 'familiness' (Habbershon et al., 2003). Resources influenced by familiness relate to human and social capital, patient financial capital, survivability capital, and governance structures and costs, which create a unique competitive advantage for a family firm (Sirmon and Hitt, 2003, p. 345). Recent studies argue that the examination of the influence of family in such resources needs to also consider the creation, integration, and exchange of knowledge within a family business, and between the business and its context (Cabrera-Suárez et al., 2018). As various definitions abound and serve different research purposes (Diaz-Moriana et al., 2019; Howorth et al., 2010; Astrachan et al., 2002; Chua et al., 1999; Westhead and Cowling, 1998), this study focuses on a definition that highlights strategy and resources. In this study, a family business will be considered as a firm where family members participate in the business and own enough equity to be able to exert control over strategy (Howorth et al., 2010). Such a definition is important, as strategy deals with the direction and scope of an organisation over the long term, achieving advantages in a changing environment through the configuration of resources and competences, with the aim of fulfilling the values and expectations of powerful actors in an organisation (Johnson et al., 2008, p. 3).

The importance of a definition for cross-cultural studies of strategic behaviour in family firms relates to examining family-oriented vs. business-oriented decision making (Basco, 2014). Family-oriented decision making relates to the advantages (e.g., monitoring and control, longterm perspectives, decision making, culture, among others) and disadvantages (e.g., lack of succession planning, nepotism, professionalisation, among others) of family involvement in how a firm is governed and managed, which can provide every family business with unique strategic choices (Basco, 2014). Business-oriented decision making relates to how organisations compete successfully in the marketplace when the family participates in the firm, focusing on efficient operations to achieve lower costs than competitors as regards raw material suppliers, internal processes such as inventories, human resources and technologies, distribution channels, as well as sales and marketing techniques (Basco, 2014, p. 974).

Differences in the way family-oriented and business-oriented decision making influence family firms can be expected in studies across countries (Au et al., 2018). Au et al. (2018), 
drawing on a quantitative study of 959 family firms from 26 countries, argue that there are cultural-dependent countervailing effects on the strategic behaviour within family firms. Their study posed that multigenerational family involvement is positively related to strategic renewal that is, the process by which family firms adapt to changing conditions in their environment to ensure survival (Sievinen et al., 2019). Basco (2014), on a study of 732 firms across several sectors and geographical regions within a country, evidenced that when a family's involvement alters the firm's decision making in different areas (such as human resources, strategic processes, and succession), then a family-enterprise-first firm - that is, a firm that combines business and family-oriented decision making - can emerge and create the conditions for a product differentiation strategy. Thus, further studies of product differentiation as a strategy in family businesses across countries are needed.

\section{Product differentiation}

Product differentiation is a strategic choice that demands extensive knowledge of a product, shared commitment of those involved, and a substantial resource investment without any certainty of success (Harrigan, 1980). Differentiation advantages typically arise from a customer's perception that a particular product is more valuable. The 'fit' of the product characteristics to market needs, as well as the firm's ability to market such characteristics, creates a differentiation advantage (Galdeano-Gómez et al., 2008). Thus, a differentiation strategy may focus on the benefits or qualities of a product or service by creating something unique. The key difference from non-family counterparts is that family firms can 'fit' together business- and family-oriented decision making and strategic behaviour to achieve better performance (Basco, 2014).

For farming families, product differentiation may be a relevant strategic choice for several reasons. First, because international markets differentiate products based on tangible (e.g., physical attributes) and/or intangible features (e.g., production processes and/or trade practices, environmental sustainability) (Carvalho et al., 2016), farming families may then engage in a unique differentiation approach, based on family and contextually-influenced resources (Roscoe et al., 2013). Second, as a differentiation strategy focuses on the benefit or quality of a product or service by creating something unique (e.g., design, quality, or innovation), then family businesses may compete based on both family and business features not offered by competitors (Basco, 2014). In the context of family-oriented and business-oriented objectives, Basco (2014) argues that commitment to value or trust may allow a stewardship culture to emerge. 


\section{A stewardship perspective}

For farming families, differentiation may challenge a traditional approach to managing existing resources. Land tenure is associated with farming families because farms are most often the exclusive source of income and residence for a family (Alsos et al., 2011). Thus, there is an implicit and powerful motivation to engage in strategies that can safeguard a family's livelihood and lifestyle (Jervell, 2011). Protecting a family farm may be underpinned by a stewardship perspective, which helps to understand the behaviour of family (and non-family members) members acting like stewards, looking after the common good of the family business (Davis et al., 2010).

Stewardship theory assumes a relationship-based system with a focus on non-financial objectives, explaining situations in which individuals serve the organisational good (Davis et al., 1997), based on an intrinsic desire to pursue collective goals, and relying on trust as a control mechanism (Madison et al., 2016). Such a perspective explains how and why family firms are differentiated from their non-family counterparts (Miller et al., 2008). A stewardship lens is relevant for this study, as it is based on the recognition that family business owners and managers are not always self-serving, and that goals and motivations can be aligned as understanding about who they serve, which includes the whole organisation in the long run (Davis et al., 2010). Based on such features, recent studies advocate that stewardship practices and behaviours are more likely to be evident in family firms than in non-family firms (Neubaum et al., 2017; Madison et al., 2016). Dodd and Dyck (2015, p. 314) argue that longer-term commitment to their firm, reputation enhancement through engaging in stewardship activities, and shared identification of members with core cultural values may explain why family firms place greater emphasis on stewardship.

Le Breton-Miller and Miller (2018, p. 233) advocate that in family firms stewardship benefits from devoted and disciplined stewards. Such individuals may engage in entrepreneurial stewardship - that is, when family business members engage with growing the family assets entrepreneurially, not just safeguarding them for the next generation (Discua Cruz et al., 2013, p. 39). Entrepreneurial stewards can relate to individuals that integrate shared interests, act upon a concern for the long-term welfare of the family business and its immediate environment rather than self-interest, and are involved in the creation and leverage of key resources within the firm (Le Bretton Miller and Miller, 2018; Dodd \& Dyck, 2015). Product differentiation could emerge as a behaviour of entrepreneurial stewards when the intention is a collective approach to improve a family firm (Vega Solano \& Discua Cruz, 2017). This may occur when a collective approach 
that relies on shared vision and commitment, the leverage of existing resources, as well as the creation of exchange networks based on diverse relationships, is encouraged. This perspective connects appropriately with a differentiation strategy in family firms put forward by Basco (2014), which draws on an organisational culture that emerges from the intertwinement between family and business, and the nurturing of internal and external stewardship relationships. Yet there is limited understanding as to the extent to which these perspectives could explain the behaviour of family businesses in industries where product differentiation is imperative (e.g., coffee (Donnet et al., 2007)).

This study acknowledges the uncertain nature of business-oriented and family-oriented decision making (Basco, 2014) when products are differentiated in a coffee farming context. Such uncertainty suggests that courses of action and decisions are explored by members of an entrepreneurial farming family through dialogue and interaction with others (family friends, potential customers, trading counterparties and financing agents, and government officials) and a place, in a process of 'articulation,' of slowly exploring how things or ideas (e.g., differentiation) unfold (Roscoe et al. 2013). Recent studies show that farming families can pursue opportunities that are based on strategies which are aligned to family members' perspectives, as well as influenced by the context in which they operate (Fitz-Koch et al., 2019). This occurs because exploring diverse options may be as dependent on the aspects of a place, such as local climate or natural features (water, soil, climate, sun) and fauna, as they are on the farming family, the community, the available resources, or market demand. Thus, product differentiation may be contingent on family members engaging in entrepreneurial stewardship and operating in specific temporal and geographical instances.

\section{Contextual Aspects in the Coffee Industry}

Coffee is one of the most consumed products around the world (Tucker, 2017). In 2017, the top ten coffee-producing countries were Brazil, Vietnam, Colombia, Indonesia, Ethiopia, Honduras, India, Uganda, Mexico, and Guatemala (de Toledo et al., 2017). Producers worldwide are challenged to find ways to transform and add value to their coffee (Ponte, 2002; Reinecke et al., 2012). Coffee-farming families may face diverse contextual pressures that may prompt diverse strategic responses, including product differentiation (Kilian et al., 2006). Key influences for coffee farming families can be understood through Wright et al.'s (2014) levels of contextual importance (organisational, institutional, and temporal). 
Table 1 shows that in terms of a temporal dimension, the coffee sector can be influenced by market shocks, trends, and demands. Declines in coffee prices can have a profound impact across coffee-producing regions, as they influence land use decisions and consumer demand over time. The last two decades have seen the emergence of geographic indications, appellations of origin, and specialised certification as mechanisms to guarantee the quality and attributes that global markets demand from coffee (Paz Cafferata and Pomareda, 2009). Consumer demand for differentiation in coffee has been growing significantly, relying on intrinsic characteristics or perceived product attributes that relate to place, process, and circumstances by which the coffee is cultivated, produced, processed, and marketed (Mizumoto, 2009; Lara Estrada et al., 2017).

In terms of an institutional dimension, farming families are strongly influenced by local legal frameworks, government systems, and worldwide policies. For example, Reinecke, Manning and Von Hagen (2012) suggested that 'meta standardisation' of sustainable practices, which relates to the process by which different standards from various contexts become interconnected to form a new and universal standard, may drive the device of institutional policies to regulate coffee production or commercialisation. Moreover, Rueda and Lambin (2013) argue that the trends impulsed by gourmet, eco-concerned consumers are modifying the coffee value chain, changing the landscape in coffee-producing countries worldwide, with more producers changing their business models to standardisation in order to benefit from price stability and exclusivity contracts. For some countries, the coffee sector represents not only one of the largest contributors to gross domestic product (GDP) and foreign direct investment, but is also a component of national identity.

Regarding the organisational dimension, Table 1 shows that whilst farming families may benefit from idiosyncratic resources (Sirmon \& Hitt, 2003), they also often deal with restricted financial resources, the limited skills and knowledge of their family, unpredictable working conditions, and complex family-work dynamics. Taken together, the items described in Table 1 suggest that farming families who engage in product differentiation may follow a risky path in trying to safeguard their families' livelihoods.

\section{Specialty coffee}

Speciality coffee is a sector characterised by distinct approaches to sourcing, processing, brewing, and serving coffee, aiming to create a unique product. In addition to claims of superior taste, specialty coffee companies celebrate the craftsmanship of coffee roasting and preparation around specialised roasting processes, product freshness, and a deliberate differentiation from 
bulk commercial grade coffees (Bacon, 2008). In particular, estate-grown coffee, as designated by the Specialty Coffee Association of America (SCAA), comes from a specific coffee farm and is grown with a standardised technique to achieve a unique taste. For instance, to capture the value offered in the specialty market segment, high-quality coffees are often associated with and named after their places of origin (e.g., Jamaican Blue Mountain) (Donnet et al., 2007). Yet, producing estate-grown coffee usually involves higher costs and specific and stringent quality standards compared to commercial bulk versions (Niederhauser et al., 2008), suggesting the importance of diverse and specialized skills as well as building up an exchange network (Howorth et al., 2014). Further understanding of how and why some families engage in coffee differentiation and the extent to which they can influence such strategic choice is warranted.

\section{Method}

To further understand how and why coffee farming families engage in product differentiation and the extent of their influence, this study is concerned with the experiences and views of those involved in family firm management. Depth rather than breadth was deemed important, and thus detailed and in-depth insights were needed (Stake, 2008). Qualitative methods are ideal to capture detailed perspectives and provide a more valid explanation of what is going on in family firms. An interpretivist perspective based on the narratives of families in business (Hamilton et al., 2017) and multiple case study design (Reay and Zhang, 2014) was considered as the best way to reveal the motivations and rationale behind decisions and practices. Case studies represent an established approach within the methodological canon of family business research (Melin et al., 2014). Reay and Zhang (2014) pose that a comparative case study approach allows moving beyond a single case study within a place to a comparison of cases, which allows a richer perspective.

Cases were selected based on where "the processes being studied are most likely to occur" (Denzin and Lincoln, 2000. p. 370), which for this study were coffee-farming families engaged in specialty coffee production. We deliberately sought out family firms in Central America that were representative of what we wanted to study, which in this case were family firms that engaged in producing estate-grown coffee. This study focuses on three countries: Guatemala, Honduras, and Nicaragua, which share a common history yet have developed differently (Black, 2018); family firms and coffee production are deeply influential in these nations. 
As the case selection was purposive, we needed privileged access. To address the difficulty of obtaining information from family businesses in Latin America (Jones, 2004), the personal relationships of the authors with the selected businesses facilitated the setting up of indepth interviews. Case studies of purposefully selected firms provided a systematic way of looking at processes and events, observing contemporary phenomena within real-life contexts, gathering and analysing data, and reporting results (Leppäaho et al., 2016). Furthermore, case studies from multiple countries were selected in order to provide more insight into coffee differentiation and to help add external validity (Riege, 2003). Evidence was gathered through interviews with the family members directly responsible for strategic decision making. On average, the interviews lasted between two and three hours and were conducted on the premises of the family farms. Names have been changed due to anonymity requests by interviewees.

\section{Guatemala: The Santa Ana Farm}

Guatemala has a population of around 16.7 million and a GDP of about US\$75.6 billion (World Bank, 2017). Coffee production in 2017 was about 3.1 million 60-kilogram sacks, representing around US\$500 million for the Guatemalan economy (ANACAFE, 2017; USDA, 2017). The United States, Japan, and Canada are the top export markets. The Santa Ana farm is located in the Antigua region of Guatemala. Antigua is internationally renowned for its high-quality coffees and is located between three volcanoes in a valley with an ideal climate for cultivating coffee. The farm was acquired by Augusto Soto in 1943 and has belonged to the Soto family for three generations. To date, Santa Ana has an annual production of 290 quintals ( 1 quintal $=100$ kilograms $/ \mathrm{kg}$ ) of coffee beans. In 1988, most coffee producers in Guatemala had no incentive to improve quality or to differentiate their product. As the ICO agreement expired in 1988, the Soto family evaluated the idea of exiting from coffee farming through the sale of arable land for real estate development. Roberto, a third generation member, argued that focusing on existing production could "save the farm and honor the family legacy". Roberto and his wife Clara were entrusted to differentiate their estate-grown coffee in order to save the family firm.

\section{Honduras: The San Antonio Farm}

Honduras has a population of around 9.2 million and a GDP of about US\$22.9 billion (World Bank, 2017). Honduras is currently the largest coffee producer in Central America, the third largest in Latin America, and the sixth largest globally, in coffee exports by volume, with a production in 2017 of about 6.5 million 60-kilogram sacks (USDA, 2017). Coffee represents around $10 \%$ of its GDP. The San Antonio farm, located in the region of Guaimaca, has been 
owned by the Rojas family since 1930 . Guaimaca has been increasingly heralded for the quality of its coffee, due to its topography, soil variety, and microclimates (IHCAFE, 2017). The farm was started by Antonio Rojas and there are currently two generations working on the farm. Yet over the years, disease, combined with a drop in international coffee prices, created issues for the firm. The Rojas family decided to support Lester, a member of the third generation, to lead a differentiation project for the family coffee business. San Antonio had traditionally sold their coffee to Honduran coffee exporters through bulk packaging but decided to engage in exporting their own estate-grown product, 'San Antonio Guaimaca Estate', in 2015. To date, San Antonio has an annual production of 500 quintals of high-quality coffee beans, with equal amounts exported to the United States and Italy.

\section{Nicaragua: The Santa Gertha Farm}

Nicaragua has a population of about 6.2 million and a GDP of about US\$13.8 billion (World Bank, 2017). Coffee is the most important crop in Nicaragua, due to its economic, social, and environmental impact (Kühl, 2004). In 2017, Nicaragua exported around three million quintals, generating US \$446 million for the economy (CETREX, 2018). The Santa Gertha farm was founded in 1977 by the Schmidt family, descendants of German immigrants, in the Matagalpa region. This region is known as an ethnic enclave, where the first coffee plantations of Nicaragua were started by German immigrants. Over the years, the Schmidt family developed different businesses in the agroindustrial and tourism sectors, including estate-grown coffee. The founders, Hans and Heidi, have four daughters, but only the oldest, Melissa, is involved in the business. The remaining three daughters are indirectly involved in the companies (exporting coffee to the US, and by online sales). During the 1980s, the Schmidt family had to leave the country, due to the Sandinista revolution (Cervantes-Rodriguez, 2006). The family fled to the United States, where the daughters completed their university education and married. The family returned to Nicaragua after democratic governments were re-established in the 1990s and reclaimed their farm. Their coffee began to be exported as an estate-grown origin product in 1992, with the name 'Café Gertha Matagalpa'. In 2017 they exported around 5,000 quintals, with $80 \%$ going to the United States and the remainder to Spain.

The initial data analysis was in Spanish; translation into English was done later. Interpretive methods were used to analyse how and why coffee differentiation was pursued by family members. The early stages of the analysis included categorizing responses to differentiation aspects alongside a pattern search. Data analysis was inductive, as the study sought to understand individual perceptions and experiences (Grbich, 2007). The search for 
meaning led us to gain an in-depth understanding of meanings and diverse perspectives about the motivation and rationale behind coffee differentiation. Based on Neergard and Leitch (2015), the authors started by independently examining the data in interviews, observation notes, and documents. Then, a coding process was carried out by reading and re-reading transcripts, notes and documents, and then using codes for sentences or paragraphs in order to organise data. Once coding was completed, data were organised to identify emerging themes, which were discussed by the authors in order to refine interpretations. Analysis of the data was reiterative in moving between data and emerging findings (Alvesson and Skoldberg, 2000). The interpretation of emergent findings was discussed with case study participants in follow-up interviews to gain their perspectives and to inform ongoing analysis. In analysing the data, experience of the Guatemalan, Honduran, and Nicaraguan cultures was important - as was experience in being part of family businesses in such countries - in order to increase understanding and confidence, which minimised disagreements in the analytical process (Discua Cruz et al., 2012; Zahra et al., 2006). Finally, findings were 're-contextualised' by comparing them to arguments in existing literature (Neergard and Leitch, 2015).

Table 2 summarizes the data coding, themes, and concepts that emerged in the process. In the findings section, compelling excerpts from the data are used to effectively illustrate the arguments made. Manual analysis methods and data in tables support the key themes emerging from the analysis (Pratt, 2009). The aim was to increase transparency and address the validity of the article (Gibbert and Ruigrok, 2010).

\title{
- INSERT TABLE 2 AROUND HERE -
}

\begin{abstract}
Analysis
Analysis of the data revealed that business-oriented and family-oriented decision making influenced the approach and rationale of families engaging in coffee differentiation. Familyoriented sources, such as succession processes, family, human, and social capital, as well as business-oriented sources such as changing customer demands, institutional practices, and diverse governmental systems, influenced the rationale of farming families in their forays into product differentiation.
\end{abstract}

\section{Differentiation through shared vision and commitment}


Evidence suggests that differentiation was driven by shared visions, represented by a collective understanding of the future that a family in business wanted to create, which for these families revolved around a commitment to be involved in the development of a differentiated product by looking after not only the family assets but also the environment and communities where their coffee is produced. Table 2 shows that in all cases, family members - as entrepreneurial stewards - displayed shared understandings shaped by prior successes, failures, and challenges. A shared vision to be in business together and offer a unique product allowed all families to move from commercialising an undifferentiated commodity to offering a certified estate-grown coffee, a sought-after brand in the specialty coffee market.

A shared understanding to bring out the best features of their products was influenced by the families' frustration about neglecting their unique product in the past. This was the case with Santa Ana and San Antonio, where the local prestige of their coffee had been diluted, as in prior decades international markets did not demand - or were unwilling to pay a premium price for their high-quality coffee. Moreover, the lack of such demand hindered their investments into dedicated coffee processing facilities, which, in addition to initial low production volumes of high-quality coffee, meant that their coffee beans had to be mixed with beans purchased from other nearby producers who were not committed to quality. As a result, their coffee ended up as a diluted and undifferentiated product.

In addition, a shared vision was grounded on the long history of family involvement in coffee production and their permanence in their location. Evidence revealed that coffee from each case had always been known for its quality since their first harvests (Table 2). A shared vision instilled by founding generations - to be known as producers of high-quality coffee influenced entrepreneurial stewards' commitment to safeguard a family heritage in coffee production whilst balancing decisions based on latest market demands. Lester (San Antonio) expressed:

"We have been doing this [high-quality coffee production] for three generations, our history is linked to this place [Guaimaca], we all wanted that customers realised that our dedication to produce the best coffee comes from looking after these lands for a long time.... [yet] this is a business and we cannot live out of family sentiment alone, we have to compete with the best product possible and that depends on us bringing out the best about this place...".

A collective vision to produce high-quality coffee as a family over time was shared by entrepreneurial stewards, who noted family responses when diverse contextual crises appeared. This was recorded when family members were forced to leave their business to later return and 
reinitiate operations (Santa Gertha), when extended family encouraged the divestment of the coffee farm following the expiration of the ICO agreement (Santa Ana), or when coffee production was perceived as less profitable in lieu of other agricultural products in the long term (San Antonio).

Table 2 shows that a shared vision also involved looking after their immediate environment. For example, entrepreneurial stewards committed themselves to look after their geographical location by using only organic methods and relying only very occasionally on chemical aggregates for soils. In San Antonio and Santa Gertha, some workers live within the farm properties and are thus motivated to look after the place where they live and work. Novel recycling methods allowed the use of no more than three cubic metres of water per quintal of processed coffee; this approach reduces water pollution substantially compared to previous methods. Wastewater was treated at the end of the process. Coffee was both naturally sundried or dried in ovens that are fuelled by coffee husks, thus encouraging minimal waste. Environmental sensitivity (e.g., a gradual switch to hydro and solar energy in San Antonio and Santa Gertha) and respect for nature (e.g., it is strictly forbidden to hunt or capture living species in Santa Gertha) was shared by family members in all cases. A shared vision of improving the community and the environment, and its importance from a business standpoint, was encapsulated by Hans from Santa Gertha:

“...30 years ago, the idea of gourmet coffee was born in the United States, so marketers are looking for farms that meet several requirements. The more requirements they have, such as height, history, location, managed by the family, that coffee is grown under shade, that the area has not been deforested, that the animals in the mountains are not hunted, that the social conditions of the employees are good, that the place is always clean... then the price improves..."

Table 2 shows that in all cases, the surrounding community was central in the shared vision of entrepreneurial stewards to differentiate their products. For example, in Santa Gertha, around 200 permanent workers work and live on the property, and have homes that have basic services, including food, energy, and education subsidised by the family business. Santa Ana and San Antonio support activities that improve technical education and raise the living standards of non-family employees. In the case of Santa Gertha and San Antonio, many of the current members of their managerial teams were born on the farm premises and are the offspring of senior employees who live nearby. Such non-family members perceive themselves as stewards of a legacy of how these families combine looking after their communities and the production of high-quality coffee over time. 


\section{Differentiation through leveraging and combining traditional and specialised knowledge}

Differentiation based on stewarding resources entrepreneurially involves family members leveraging resources over time and building on them through a combination with new resources. This approach was evidenced in the combination of traditional and specialised knowledge by entrepreneurial stewards in coffee production, which influenced both business and familyoriented decision making. 'Traditional' in this case relates to the indigenous skills, knowledge, and techniques accumulated by family members, which is derived from the interaction with the environment and has been in existence for at least 100 years (Barrios and Trejo, 2003; Grossman, 2003). Traditional, a priori, knowledge (cultivation, weeding, soil management) was generated by the personal experiences of prior generations, whilst specialised, a posteriori, knowledge relates to the use of scientific applications for coffee productivity (e.g., ethnopedology) (Ericksen and Ardón, 2003; Winklerprins, 1999).

Table 2 shows that entrepreneurial stewards identified that coffee trends were favouring high-quality 'traditional' coffee and that differentiation, based on traditional knowledge to bring out such features in coffee, was relevant, but also that new techniques were needed. This was noted by Roberto, from Santa Ana:

"Coffee traders in developed countries became concerned about their profits declining in mixed quality varieties of coffee. Some traders encouraged 'nostalgia' in their customers, who gradually demanded 'old-fashioned' traditional coffee. Niche markets were then created for consumers willing to pay a premium price for top-quality coffee ... We became interested in this trend as it was evident that there was a market ready to consume a differentiated product. It was our only window of opportunity to achieve an advantage."

In all cases, knowledge about high-quality coffee production in a particular place was transferred from one generation to the next, as family members lived on the farm and were socialised from childhood into estate-grown coffee production (e.g., cultivation, harvesting, and processing). Transgenerational knowledge exchange may have undergone successive refinement, leading to a system of understanding of natural resources and relevant ecological processes (Pawluk et al., 1992) in coffee production. Access to such knowledge made family members perceive themselves as stewards of traditional skills and techniques within a geographical location. Such knowledge helped entrepreneurial stewards identify and build on outstanding characteristics of their coffee plantations to cater for the demand of 'traditional coffee' local to their places (Antigua, Guaimaca, and Matagalpa). 
Yet, traditional knowledge was influenced by the fact that coffee production was a primary concern, while specialised knowledge entailed a more holistic view of plant productivity (Ericksen and Ardón, 2003) and coffee management practices. Specialised agricultural engineering degrees or education in subjects related to the management of agricultural ventures and marketing were pursued, locally and overseas, by entrepreneurial stewards. Such practices were geared to influence decision making based on family and business objectives (Basco, 2014). In addition, families sought support from experts from local governmental agencies (Santa Ana, San Antonio) and foreign technicians (Santa Gertha). For instance, Santa Gertha relied on non-family German experts for specialised knowledge in coffee production while family members focused on coffee commercialisation. In Santa Gertha, the forced migration of the family to the USA allowed family members to learn about a growing demand for estategrown coffee from farms that could attest to their heritage and also provide evidence of traceability for new markets. New techniques in monitoring and commercializing coffee (Niederhauser et al., 2008) have been introduced by entrepreneurial stewards. San Antonio and Santa Gertha have catalogued every hectare of their coffee fields by GPS, so that now they can monitor field production and maintenance as well as sell their estate-grown coffee with a designation of very precise origin.

Evidence across cases also highlighted that knowledge passed down from generations was combined with technical knowhow brought forward by incoming generations. For instance, Santa Ana and San Antonio junior generations, due to pursuing specialised degrees in agricultural engineering, could identify the temperature range that gave coffee plants an ideal environment and the type of soil where coffee was best cultivated to support its maturation process and reach high-quality estate status. Knowing such factors in detail, combined with traditional methods, favoured the quality of coffee produced (Lara Estrada et al., 2017) and addressed diverse climatological problems (such as frost and drought). In all cases, coffees cultivated by these families were harvested on mountains, with altitudes ranging between 1,200 to 1,500 metres above sea level. Such features were known over generations to be critical not only for coffee quality but also for the minimal occurrence of coffee diseases and for experimentation in terms of new coffee varieties that could be introduced by using new techniques. Combining traditional and specialised knowledge allowed that at least three varieties of coffee could be grown in all the farms, so sowing density was optimal per square metre of land. Coffee parasites were handled in an environmentally friendly manner, using traps (traditional techniques used by Santa Ana and San Antonio). Annual rainfall for all farms was optimal for all cases, between 850 to $952 \mathrm{~mm}$. Alternative irrigation was drawn from man-made 
wells when needed, which helped reach consistency in the quality of coffee produced (Santa Ana, Santa Gertha). All cases added value to a quality bean, produced exclusively on farm premises and avoiding any mix with other beans.

The cases reveal that as agriculture is highly dependent on the local environment, traditional knowledge was of particular importance, as it contained a cherished understanding of the particular set of local cultural and natural resources possessed by family members. Such knowledge, when combined with scientific knowhow, technical practices, and skills both in coffee production and commercialisation, can influence the approach to a differentiated product over time by entrepreneurial stewards. The qualities that differentiated the estate-grown coffee in every case were its origin, coffee bean variety, cultivation and preparation process, supported by the combination of traditional and scientific knowledge. When such properties were technically understood, they provided distinctive features that highlighted both the heritage of coffee produced by a family in a place and novel techniques.

\section{The creation and development of a support and exchange network}

The evidence suggested that entrepreneurial stewards engaged in nurturing and leveraging new and old family and non-family ties, external recognition, and commercial alliances. Developing an exchange network that encompasses support, customer, and supplier networks (Casson and Giusta, 2007; Shaw et al., 2017) was paramount for a differentiation strategy.

Lester, from San Antonio, encapsulated such importance when expressing:

"... Good family relationships help out because they will try to help you get what you need, whether it is funds, insight about coffee, or customers for your products. Yet because coffee is widely available here, then connecting with international consumers is crucial... foreign buyers know what they are looking for, they have different methods, but we realise that they want to know more about something we take for granted - this place! That is why we added the Guaimaca aspect. Good relationships with them [customers] will go a long way in business... I am sure if we start winning more competitions we can then go back to the negotiating table and ask for better prices, we can then improve the farms and bring up the reputation of coffee produced in this place...we can then assure clients for the long run and our relationship will be stronger...."

Family exchange networks were relevant when the focus on a differentiated product demanded additional investments in modern processing plants. Table 2 shows that for Santa Ana and San Antonio, family networks were critical when attempting to procure access to external 
funding for product differentiation. In these two cases, families activated ties in banking to facilitate access to bank funds. In Santa Gertha, entrepreneurial stewards were supported with cash and interest-free loans. In every case, such funding allowed new coffee plants to: increase cultivation density; make organic fertilisation programs become widespread; make pruning and shading for coffee bushes a priority; and put previously idle farm land to use. Funding procured through family networks allowed farms to achieve a consistent quality and thus helped to produce high-quality, estate-grown coffee.

Non-family exchange networks were also gradually shaped through the creation and nurturing of relationships with diverse actors related to coffee commercialisation. Santa Ana and San Antonio entrepreneurial stewards have developed good relationships with governmental offices dealing with coffee commercialisation. This approach allows coffee-farming families to keep updated on opportunities to promote their products. Since the year 2000, the Guatemalan (ANACAFE) and Honduran National Coffee Association (IHCAFE) have shown a shift in government policy towards collaboration with the private sector. In addition to technical support, these organisations have organised regional and national competitions, such as the 'Cup of Excellence' auction, a competition where an expert group of national and international judges selects the best coffee produced in a particular year and rewards high-quality coffee producers (Teuber and Herrmann, 2012). The contest winners have samples of their coffee sent to specialty coffee buyers throughout the world. The Santa Ana sample, labeled 'Genuine Santa Ana Antigua', has won a third-place prize in the past, while San Antonio's 'San Antonio Guaimaca Estate' coffee achieved an invitation last year, yet has not won a prize to date. Such interaction favoured the relevance of traditional family knowledge in coffee production as well as providing new information for business-oriented decision making.

By participating in competitions, entrepreneurial stewards gradually developed relationships with interested consumers and encouraged the emergence of alliances. As Santa Ana coffee began gaining recognition, a large retail company became interested in their product. This retail company establishes alliances for supplying coffee to the USA with one sole strategic focus - quality. As a result of being recognised, retailers pay a higher price per sack compared to the average paid at the New York Sugar, Coffee, and Cocoa Exchange (NYSCCE). The potential for other major players to secure the production of Santa Ana coffee has prompted other international buyers to offer exclusive rights by guaranteeing a fixed price for the product. Moreover, Santa Ana's commitment to address environmental concerns within their immediate community has impacted on the preferences of new consumers. A large US customer paid preferential rates when social and environmental issues were addressed (Table 2). The price 
increase allowed Santa Ana to improve the differentiating features of their specialty coffee and at the same time benefit their community in the long term.

In San Antonio, entrepreneurial stewards are now committed to continue participating in coffee competitions guided by IHCAFE staff. Alliances in high-quality coffee production began in 2015, when Anibal, who studied a master's degree in agriculture in Italy, managed to contact a large Italian retail company. The Italian company asked for samples and was fascinated by the blends they could create. In San Antonio and Santa Ana, representatives from large retailers visited the farms and secured exclusive coffee procurement. Moreover, such external relationships advised that the features of the place where coffee was planted and harvested needed to be included in future promotions. In doing so, entrepreneurial stewards were interested in creating new ties in various networks to leverage relationships in the long term.

Santa Gertha has opted not to participate in such competitions, due to scepticism about governmental support or intervention. Yet, 'Café Gertha Matagalpa' is strongly positioned in Nicaragua because of the promotions made by foreigners living in the country and the inhabitants of Matagalpa, many of whom are of German origin and promote products made by fellow migrants. For Santa Gertha, alliances emerged as their coffee began to be exported as a 'coffee of origin' in 1992 with the name of 'Café Santa Gertha' to the United States; the importer recommended that the name be changed to 'Café Gertha Matagalpa', because it sounded more romantic and highlighted the features of its place of origin, a name that has lasted to date. Contrary to Santa Ana and San Antonio, Santa Gertha has managed to position itself adequately in the international market due to in-house marketing. They have patented their name in the USA and associated it with international certifications. Their coffee is consumed by elitist associations in the USA, who require coffee with high quality and the same consistency as the previous year. Meeting such specifications demands control of the coffee variety and a commitment to promote the unique features of the Matagalpa region. Addressing such demands allows 'Café Gertha Matagalpa' to achieve a higher price.

In all cases, and motivated by increasing demands from customer networks about traceability and QR codes (Dabbene et al., 2014), information about every batch includes specifications such as height, precipitation, soil composition, sun exposure, and bean variety.

The gradual development of an exchange network, comprising the combination of existing ties (e.g., family support for business growth) and new ties (e.g., proactive engagement in competition to promote alliances) has allowed the shaping of the uniqueness of a product, as well as catering for changing customer demands internationally. Leveraging existing and new 
relationships have influenced the decision-making approach of farming families to engage in product differentiation based on family and business aspects.

\section{Conclusion}

This study embarked on understanding how and why family businesses in the coffee industry engage in product differentiation and to what extent family influence product differentiation in the coffee industry. A shared vision and commitment, knowledge, and leverage of traditional and novel ways of producing high-quality coffee, and the gradual shape of an exchange network by entrepreneurial stewards underpin how and why product differentiation is engaged. Moreover, product differentiation in specialty coffee farming farms appears to be associated as much with a strategic choice as with an entrepreneurial outcome influenced by families. Intrinsic characteristics or perceived attributes within a place, as well as the ways by which entrepreneurial stewards approach how coffee is produced, processed, and marketed over time, are relevant in product differentiation in family businesses.

\section{Theoretical contribution}

This study contributes to the literature by comparing coffee family farms across Central America. In doing so, this study contributes to stewardship literature in family firms in two ways. First, findings suggest that a product differentiation strategy may be engaged through devoted and disciplined individuals (Le Breton-Miller and Miller, 2018) who behave entrepreneurially (Discua Cruz et al., 2013). Such entrepreneurial stewards encourage a commitment among family members to bring out the unique features of their product, without neglecting a caretaking approach for their environment. In addition, entrepreneurial stewards can combine traditional and newly-acquired expertise to create a complex set of knowledge. Finally, they can develop an exchange network grounded on family support, as well as proactive engagement in business competitions and alliance development.

Second, by engaging in a cross-cultural comparison, the findings extend our understanding of entrepreneurial stewardship by revealing that a differentiated agricultural product, offered by a family firm over generations, demands a collective vision and approach (Fitz-Koch et al., 2019; Roscoe et al., 2013). The rationale relates to family members' long-term vision to be in business together and a shared commitment to look after the family's assets over time (Discua Cruz et al., 2013). This is further supported by the intention of entrepreneurial stewards to look after a tradition of producing a high-quality product over generations through 
leveraging existing and new resources whilst looking after the community and environment that influence such outcomes.

In terms of strategic behaviour, this cross-cultural study expands our understanding of family-enterprise-first family firms, as the findings suggest that the gradual development of a dual knowledge system and an exchange network allows families to fulfil a shared vision. A knowledge perspective on coffee production has its roots in the resource-based perspective of a family firm, which assumes that diverse and distinctive resources (valuable and rare, difficult to imitate and substitute), may allow family firms to process information and capabilities in order to achieve competitive advantages (Barney et al., 2001). The early involvement of younger members has the potential to produce deeper levels of firm-specific tacit knowledge (Sirmon and Hitt, 2003, p. 342). Still, it is in the ability to transfer knowledge (Lobley, 2010) and combine it with new knowledge that such resources (e.g., human capital) can be associated with higher levels of performance. Such a combination makes knowledge used in differentiation appropriable, scarce, highly specialised, and difficult to imitate, whilst remaining associated with the family realm (Chirico and Salvato, 2016). Leveraging traditional and specialised knowledge can endow entrepreneurial stewards with a forward-looking balance of skills and competencies relevant for business decision making (Basco, 2014; Cabrera-Suárez et al., 2018). Moreover, the findings extend our understanding of organisational cultures that can emerge from the nurturing of internal and external stewardship relationships (Basco, 2014) by revealing that strong relationships with internal and external stakeholders are nurtured for the long run, supporting both family- and business-oriented decision making that can influence strategic renewal.

Finally, this cross-cultural study contributes to understanding how context can affect strategic decisions in family-enterprise-first family firms. Disturbances or critical events, in contextual dimensions, such as a change in international policies or adverse governmental systems (Wright et al., 2014), may either minimise or reinforce the shared family vision to engage in product differentiation. A shared vision, combination of resources, and a gradual development of an exchange network can be put in jeopardy when interruptions or contextual disturbances occur (Table 1), which may unbalance the family-oriented/business-oriented decision making of a firm over time, influencing the motivation and rationale to pursue any strategy (Howorth et al., 2014). In essence, the findings and contribution of this study gravitate around the cross-cultural focus in understanding the strategies of families in business that produce specialty coffee.

\section{Limitations}


This study has a few caveats, and so its findings must be interpreted with caution. First, the sample of comparative cases is small, and the sampling logic would have been stronger if a broader sample of cases from countries with significant levels of coffee production had been included, such as Brazil, Mexico, Peru, and Colombia. Nonetheless, the sample consists of family firms that produce specialty coffee from well-established places, allowing theoretical relevance (Eisenhardt, 1989). Second, all the cases focus on individual firms and are in a single industry, thus research on family firms from other industries or across industries in different countries, where defining characteristics of differentiation can be examined in relation to a place, should be conducted (Spielmann et al., 2019); collective approaches through cooperatives should also be studied (Hadjielias and Poutziouris, 2015).

\section{Practical implications}

The findings also have practical implications for family business managers who have to design and execute strategies where family- and business-oriented decision making may be intrinsically linked to stewardship. A shared vision can be an anchor when disturbances emerge, as it embodies what the family firm is about and what it must focus on and do to survive. To move beyond involvement to commitment, a shared vision could be instilled through early socialisation in order to gradually reflect the philosophy and values of the family in decision making (Seaman et al., 2019). The importance of traditional knowledge cannot be overstated, as it serves as a means for family and non-family members to perceive themselves as custodians or stewards, influencing the agreement of common objectives in the long term. Families who fail to acknowledge the relevance of transferring and combining knowledge for improved performance and decision making (Cabrera-Suárez et al., 2018; Chirico and Salvato, 2016) may be limited in their ability to reach an optimal differentiation strategy based on both family and business aspects in the long term. Finally, the findings reveal how family businesses can build on their competitive advantage through product differentiation, which can serve not only as a relevant business strategy but also as a path to establish a relevant governance mechanism when balancing family and business goals over time (Basco, 2017).

\section{Further Research}

This study opens the door for further cross-cultural research in settings that are affected by changing contextual aspects (e.g., see Estrada-Robles et al., 2018; Basco et al., 2019), such as 
family firms producing artisanal products or engaged in tourism, manufacturing, and creative industries (music, art, film, and literature) in alternative contexts. Moreover, future cross-cultural studies focusing on diverse strategies in family businesses that produce international commodities (e.g., wine, see Spielmann et al., 2019) should consider different levels and units of analysis (Basco and Pérez Rodríguez, 2009; Discua Cruz and Basco, 2018). Finally, recent studies suggest that we should expect variation in the entrepreneurial and strategic behaviour of family firms across generations ( $\mathrm{Au}, 2018)$, and thus quantitative cross-country studies that test the relationship between entrepreneurial stewardship (Discua Cruz et al., 2013) and specific strategies in family firms (Basco, 2014) are warranted. Further studies that focus on product differentiation in family businesses across countries can support, challenge, and extend the results of this study. This study challenges researchers to expand understanding about the strategic behaviour of family firms across countries that engage in product differentiation of items consumed worldwide.

\section{References}

ANACAFE (2017). "Estadísticas de exportaciones de café de Guatemala", Asociación Nacional del Café de Guatemala. Available at: http://www.anacafe.org/ (Last accessed December 2018).

Alsos, G.A., Carter, S. and Ljunggren, E. (2011), The Handbook of Research on Entrepreneurship in Agriculture and Rural Development, Edward Elgar Publishing, Cheltenham, UK and Northampton, MA, USA.

Astrachan, J., Klein, S.B. and Smyrnios, K.X. (2002), "The F-PEC scale of family influence: A proposal for solving the family business definition problem", Family Business Review, Vol. 15 No. 1, pp. $45-58$.

Au, K. (2018), "Editorial for the special section: Transgenerational entrepreneurship in the global world", Cross Cultural \& Strategic Management, Vol. 25 No. 4, pp. 546-549.

Au, K., Han, S. and Chung, H.-M. (2018), "The impact of sociocultural context on strategic renewal: A twenty-six nation analysis of family firms", Cross Cultural \& Strategic Management, Vol. 25 No. 4, pp. 604-627.

Barrios, E. and Trejo, M.T. (2003), "Implications of local soil knowledge for integrated soil management in Latin America", Geoderma, Vol. 111 No. 3, pp. 217-231.

Bacon, C.M. (2008), Confronting the coffee crisis: Fair trade, sustainable livelihoods and ecosystems in Mexico and Central America, MIT Press, Boston, USA.

Barney, J.B., Wright, M. and Jr., D.K. (2001), "The resource-based view of the firm: Ten years after 1991", Journal of Management, Vol. 27 No. 6, pp. 625-641.

Basco, R. (2014), "Exploring the influence of the family upon firm performance: Does strategic behaviour matter?", International Small Business Journal, Vol. 32 No. 8, pp. 967-995.

Basco, R. (2017), “'Where do you want to take your family firm?' A theoretical and empirical exploratory study of family business goals", BRQ Business Research Quarterly, Vol. 20 No. 1, pp. 28-44.

Basco, R. and Pérez Rodríguez, M.J. (2009), "Studying the family enterprise holistically: Evidence for integrated family and business systems", Family Business Review, Vol. 22 No. 1, pp. 82-95.

Basco, R., Calabrò, A. and Campopiano, G. (2019), "Transgenerational entrepreneurship around the world: Implications for family business research and practice", Journal of Family Business Strategy, Vol. 10 No. 4, available at: https://doi.org/10.1016/j.jfbs.2018.03.004. 
Cabrera-Suárez, M.K., García-Almeida, D.J. and De Saá-Pérez, P. (2018), “A dynamic network model of the successor's knowledge construction from the resource- and knowledge-based view of the family firm", Family Business Review, Vol. 31 No. 2, pp. 178-197.

Carvalho, J.M., Vieira, L.M. and Paiva, E.L. (2016), "Quality attributes of a high specification product: Evidences from the speciality coffee business", British Food Journal, Vol. 118 No. 1, pp. 132-149.

Casson, M. and Giusta, M.D. (2007), "Entrepreneurship and social capital analysing the impact of social networks on entrepreneurial activity from a rational action perspective", International Small Business Journal, Vol. 25 No. 3, pp. 220-244.

Cervantes-Rodriguez, A.M. (2006), "Nicaraguans in Miami-Dade county: Immigration, incorporation, and transnational entrepreneurship", Latino Studies, Vol. 4 No. 3, pp. 232-257.

CETREX (2018): “Exportaciones de café verde de Nicaragua por mes: Cosecha 2017/2018”, Centro de Trámites de las Exportaciones, Gobierno de Nicaragua.

Chirico, F. and Salvato, C. (2016), "Knowledge internalization and product development in family firms: When relational and affective factors matter", Entrepreneurship Theory and Practice, Vol. 40 No. 1, pp. 201-229.

Chua, J.H., Chrisman, J.J. and Sharma, P. (1999), "Defining the family business by behavior", Entrepreneurship Theory and Practice, Vol. 23 No. 4, pp. 19-39.

Davis, J.H., Allen, M.R. and Hayes, H.D. (2010), "Is blood thicker than water? A study of stewardship perceptions in family business", Entrepreneurship Theory and Practice, Vol. 34 No. 6, pp. $1093-$ 1116.

Dabbene, F., Gay, P. and Tortia, C. (2014), "Traceability issues in food supply chain management: A review”, Biosystems Engineering, Vol. 120, pp. 65-80.

Denzin, N. and Lincoln, Y. (2000), The SAGE Handbook of Qualitative Research., SAGE Publications Ltd, London.

Diaz-Moriana, V., Hogan, T., Clinton, E. and Brophy, M. (2019), "Defining family business: A closer look at definitional heterogeneity", in Memili, E. and Dibrell, C. (Eds.), The Palgrave Handbook of Heterogeneity among Family Firms, Springer International Publishing, Cham, pp. 333-374.

Discua Cruz, A., Howorth, C. and Hamilton, E. (2013), "Intrafamily entrepreneurship: The formation and membership of family entrepreneurial teams", Entrepreneurship Theory and Practice, Vol. 37 No. 1, pp. 17-46.

Discua Cruz, A. and Basco, R. (2018), "Family perspective on entrepreneurship", in Turcan, R.V. and Fraser, N.M. (Eds.), The Palgrave Handbook of Multidisciplinary Perspectives on Entrepreneurship, Springer International Publishing, Cham, pp. 147-175.

Discua Cruz, A., Basco, R., Parada, M.J., Malfense Fierro, A.C. and Alvarado Alvarez, C. (2019), "Resilience and family business groups in unstable economies", in Rautianinen, M., Rosa, P., Pihkala, T., Parada, M.J. \& Discua Cruz, A. (Eds), The Family Business Group Phenomenon: Emergence and Complexities, Springer international publishing, Cham, pp. 315-352.

Dodd, S.D. and Dyck, B. (2015), "Agency, stewardship, and the universal-family firm A qualitative historical analysis", Family Business Review, Vol. 28 No. 4, pp. 312-331.

Donnet, M.L., Weatherspoon, D.D., Hoehn, J.P. and others. (2007), "What adds value in specialty coffee? Managerial implications from hedonic price analysis of Central and South American e-auctions", International Food and Agribusiness Management Review, Vol. 10 No. 3, pp. 1-18.

Donnet, M.L., Weatherspoon, D.D., Hoehn, J.P. and others. (2007), "What adds value in specialty coffee? Managerial implications from hedonic price analysis of Central and South American e-auctions", International Food and Agribusiness Management Review, Vol. 10 No. 3, pp. 1-18.

Eisenhardt, K.M., (1989), "Building theories from case study research". Academy of Management Review, Vol.14 No.4, pp.532-550.

Ericksen, P.J. and Ardón, M. (2003), "Similarities and differences between farmer and scientist views on soil quality issues in central Honduras", Geoderma, Vol. 111 No. 3, pp. 233-248.

Estrada-Robles, M., Williams, N. and Vorley, T. (2018, In press), "Navigating institutional challenges in Mexico", International Journal of Entrepreneurial Behavior \& Research, available at: https://doi.org/10.1108/IJEBR-05-2017-0180.

Fernández Pérez, P. and Lluch, A. (2016), Evolution of Family Business: Continuity and Change in Latin America and Spain, Edward Elgar Publishing, Cheltenham, UK and Northampton, MA, USA. 
Finch, J. (2002), "The role of grounded theory in developing economic theory", Journal of Economic Methodology, Vol. 9 No. 2, pp. 213-234.

Fitz-Koch, S., Cooper, S. and Discua Cruz, A. (2019), "Entrepreneurship and rural family identity: understanding portfolio development in a family farm business", in Rautiainen, M., Rosa, P., Pihkala, T., Parada, M.J. and Discua Cruz, A. (Eds.), The Family Business Group Phenomenon: Emergence and Complexities, Springer international publishing, Cham, pp. 353-383.

Galdeano-Gómez, E., Céspedes-Lorente, J. and Martínez-del-Río, J. (2008), "Environmental performance and spillover effects on productivity: Evidence from horticultural firms", Journal of Environmental Management, Vol. 88 No. 4, pp. 1552-1561.

Gibbert, M. and Ruigrok, W. (2010), "The ' What' and 'How' of case study rigor: three strategies based on published work", Organizational Research Methods, Vol. 13 No. 4, pp. 710-737.

Grbich, C. (2007), Qualitative Data Analysis: An introduction, SAGE Publications Ltd, London.

Grossman, J.M. (2003), "Exploring farmer knowledge of soil processes in organic coffee systems of Chiapas, Mexico", Geoderma, Vol. 111 No. 3, pp. 267-287.

Habbershon, T.G., Williams, M. and MacMillan, I.C. (2003), "A unified systems perspective of family firm performance”, Journal of Business Venturing, Vol. 18 No. 4, pp. 451-465.

Hadjielias, E. and Poutziouris, P. (2015), "On the conditions for the cooperative relations between family businesses: the role of trust", International Journal of Entrepreneurial Behaviour \& Research, Vol. 21 No. 6, pp. 867-897.

Hamilton, E., Discua Cruz, A. and Jack, S. (2017), "Re-framing the status of narrative in family business research: Towards an understanding of families in business", Journal of Family Business Strategy, Vol. 8 No. 1, pp. 3-12.

Harrigan, K.R. (1980), "Strategy formulation in declining industries", The Academy of Management Review, Vol. 5 No. 4, pp. 599-604.

Howorth, C., Rose, M. and Hamilton, E. (2006), "Definitions, diversity and development: key debates in family business research", in Casson, M., Yeung, B., Cassu, A. and Wadeson, N. (Eds.), Oxford Handbook of Entrepreneurship, Oxford University Press, New York, pp. 225-247.

Howorth, C., Jackson, J. and Discua Cruz, A. (2014), "Entrepreneurship in family businesses", in Chell, E. and Karatas-Ozkan, M. (Eds.), Handbook of Research in Small Business and Entrepreneurship, Edward Elgar Publishing, Cheltenham, UK and Northampton, MA, USA, pp. 333-357.

Howorth, C., Rose, M., Hamilton, E. and Westhead, P. (2010), "Family firm diversity and development: An introduction", International Small Business Journal, Vol. 28 No. 5, pp. 437-451.

ICO (2019), "World coffee consumption in thousand 60-kg bags", International Coffee Organisation, http://www.ico.org/prices/new-consumption-table.pdf (Last accessed November 2019)

IHCAFE. (2017), "IHCAFE - Instituto Hondureño del Cafe", IHCAFE - Instituto Hondureño del Cafe, available at: https://www.ihcafe.hn/.

Jervell, A. M. (2011). "The family farm as a premise for entrepreneurship," in G. A. Alsos, S. Carter and E. Ljunggren (eds), The handbook of research on entrepreneurship in agriculture and rural development, Edward Elgar Publishing, Cheltenham, UK and Northampton, MA, USA. pp. 54-73.

Johnson, G., Scholes, K. and Whittington, R. (2008), Exploring Corporate Strategy, 8th edition., Prentice Hall, Harlow.

Jones, V. (2004), “The rhythms of Latin America: A context and guide for qualitative research", in Marschan-Piekkari, R. and Welch, C. (Eds.), Handbook of Qualitative Research Methods for International Business, Edward Elgar Publishing, Cheltenham, UK and Northampton, MA, USA, pp. 439-457.

Kilian, B., Jones, C., Pratt, L. and Villalobos, A. (2006), "Is sustainable agriculture a viable strategy to improve farm income in Central America? A case study on coffee", Journal of Business Research, Vol. 59 No. 3, pp. 322-330.

Kühl, E. (2004), Nicaragua y Su Café, HISPAMER, Managua, Nicaragua.

Lara Estrada, L., Rasche, L. and Schneider, U.A. (2017), "Modeling land suitability for coffee arabica L. in Central America", Environmental Modelling \& Software, Vol. 95, pp. 196-209.

Le Breton-Miller, I. and Miller, D. (2018), "Looking back at and forward from: 'family governance and firm performance: agency, stewardship, and capabilities"”, Family Business Review, Vol. 31 No. 2, pp. 229-237. 
Leppäaho, T., Plakoyiannaki, E. and Dimitratos, P. (2016), "The case study in family business; an analysis of current research practices and recommendations", Family Business Review, Vol. 29 No. 2, pp. 159-173.

Lobley, M. (2010), "Succession in the family farm business", Journal of Farm Management, Vol. 13 No. 12, pp. 839-851.

Miller, D., Le Breton-Miller, I. and Scholnick, B. (2008), "Stewardship vs. stagnation: An empirical comparison of small family and non-family businesses", Journal of Management Studies, Vol. 45, pp. $51-78$.

Mizumoto, F.M. (2009), "Strategy and entrepreneurial action in family businesses: An analysis of human and social capital", unpublished thesis, University of Sao Paolo, Brazil.

Melin, L., Nordqvist, M., and Sharma, P. (2014), The SAGE Handbook of Family Business, SAGE Publications Ltd, London, UK.

Müller, C., Botero, I.C., Discua Cruz, A. and Subramanian, R. (2019), Family Firms in Latin America, Routledge, New York.

Neergaard, H. and Leitch, C.M. (2015), Handbook of Qualitative Research: Techniques and Analysis in Entrepreneurship, Edward Elgar Publishing, Cheltenham, UK and Northampton, MA, USA.

Niederhauser, N., Oberthür, T., Kattnig, S. and Cock, J. (2008), "Information and its management for differentiation of agricultural products: The example of specialty coffee", Computers and Electronics in Agriculture, Vol. 61 No. 2, pp. 241-253.

Pawluk, R.R., Sandor, J.A. and Tabor, J.A. (1992), "The role of indigenous soil knowledge in agricultural development", Journal of Soil and Water Conservation, Vol. 47 No. 4, pp. 298-302.

Paz Cafferata, J. and Pomareda, C. (2009), "Indicaciones Geográficas y Denominaciones de Origen En Centroamérica: Situación y Perspectivas", International Centre for Trade and Sustainable Development (ICTSD), Geneva, Switzerland, available at: https://www.ictsd.org/sites/default/files/research/2012/02/indicaciones-geograficas-ydenominaciones-de-origen-en-centroamerica.pdf (Last accessed May 2019).

Pendergrast, M. (2010). Uncommon grounds: The history of coffee and how it transformed our world. Basic Books, New York.

Ponte, S. (2002), “The 'latte revolution'? Regulation, markets and consumption in the global coffee chain", World Development, Vol. 30 No. 7, pp. 1099-1122.

Pratt, M.G. (2009), "For the lack of a boilerplate: tips on writing up (and reviewing) qualitative research", Academy of Management Journal, Vol. 52 No. 5, pp. 856-862.

Reay, T. and Zhang, Z. (2014), "Qualitative methods in family business research", In Melin, L., Nordqvist, M., and Sharma, P (eds), The SAGE Handbook of Family Business, SAGE Publications Ltd, London, pp. 573-593.

Reinecke, J., Manning, S. and Hagen, O. von. (2012), "The emergence of a standards market: Multiplicity of sustainability standards in the global coffee industry", Organization Studies, Vol. 33 No. 5-6, pp. 791-814.

Riege, A.M. (2003), "Validity and reliability tests in case study research: A literature review with 'hands-on' applications for each research phase", Qualitative Market Research: An International Journal, Vol. 6 No. 2, pp. 75-86.

Roscoe, P., Discua Cruz, A and Howorth, C. (2013), "How does an old firm learn new tricks? A material account of entrepreneurial opportunity", Business History, Vol. 55 No. 1, pp. 53-72.

Rueda, X. and Lambin, E.F. (2013), "Linking globalization to local land uses: How eco-consumers and gourmands are changing the Colombian coffee landscapes", World Development, Vol. 41, pp. 286301.

SCAA. (2019), “US coffee market overview 2018”, available at: https://scanews.coffee/2019/10/01/uscoffee-market-overview/ (Last accessed November 2019).

Seaman, C., Bent, R., and Silva, M. (2019), "Family values: Influencers in the development of financial and non-financial dynamics in family firms", in Memili, E. and Dibrell, C. (Eds.), The Palgrave Handbook of Heterogeneity among Family Firms, , Springer International Publishing, Cham. pp. 507-530.

Shaw, E., Wilson, J. and Pret, T. (2017), "The process of embedding a small firm in its industrial context”, International Small Business Journal, Vol. 35 No. 3, pp. 219-243. 
Sievinen, H.M., Ikäheimonen, T. and Pihkala, T. (2019), "Strategic renewal in a mature family-owned company - A resource role of the owners", Long Range Planning, https://doi.org/10.1016/j.1rp.2019.01.001

Sirmon, D.G. and Hitt, M.A. (2003), "Managing resources: linking unique resources, management, and wealth creation in family firms", Entrepreneurship Theory and Practice, Vol. 27 No. 4, pp. 339358.

Spielmann, N., Discua Cruz, A., Tyler, B.B. and Beukel, K. (2019), "Place as a nexus for corporate heritage identity: An international study of family-owned wineries", Journal of Business Research, available at: https://doi.org/10.1016/j.jbusres.2019.05.024.

Stake, R.E. (2008), "Qualitative case studies", in Denzin, N. and L., Y. (Ed.), Strategies of Qualitative Inquiry, SAGE Publications Ltd, London., pp. 119-150.

Teuber, R. (2010), "Geographical indications of origin as a tool of product differentiation: the case of coffee", Journal of International Food \& Agribusiness Marketing, Vol. 22 No. 3-4, pp. 277-298.

Teuber, R. and Herrmann, R. (2012), "Towards a differentiated modeling of origin effects in hedonic analysis: An application to auction prices of specialty coffee", Food Policy, Vol. 37 No. 6, pp. 732 740.

de Toledo, P.R.A.B., de Melo, M.M.R., Pezza, H.R., Toci, A.T., Pezza, L. and Silva, C.M. (2017), "Discriminant analysis for unveiling the origin of roasted coffee samples: A tool for quality control of coffee related products", Food Control, Vol. 73, pp. 164-174.

Tucker, C.M. (2017), Coffee culture: Local Experiences, Global Connections, Routledge, New York.

USDA. (2017), Honduras, Guatemala and Nicaragua data can be accessed through https://www.fas.usda.gov/ (Last accessed December 2018)

Vega Solano, M. and Discua Cruz, A. (2017), "Daring to be different: A case study of entrepreneurial stewardship in a Guatemalan family's coffee farm", in Ramirez-Pasillas, M., Brundin, E., Markowska, M. (eds), Contextualizing Entrepreneurship in Emerging Economies and Developing Countries, Edward Elgar Publishing, Cheltenham, UK and Northampton, MA, USA, pp. 274-287.

Westhead, P. and Cowling, M. (1998), "Family firm research: The need for a methodology rethink", Entrepreneurship Theory and Practice, Vol. 23 No. 1, pp. 31-56.

Winklerprins, A.M.G.A. (1999), "Insights and applications local soil knowledge: A tool for sustainable land management”, Society \& Natural Resources, Vol. 12 No. 2, pp. 151-161.

Wright, M., Chrisman, J.J., Chua, J.H. and Steier, L.P. (2014), "Family enterprise and context", Entrepreneurship Theory and Practice, Vol. 38 No. 6, pp. 1247-1260.

World Bank. (2017). Honduras, Guatemala and Nicaragua data can be accessed through https://data.worldbank.org/ (Last accessed December 2018) 
Table 1. Contextual framework in the coffee-farming context across countries

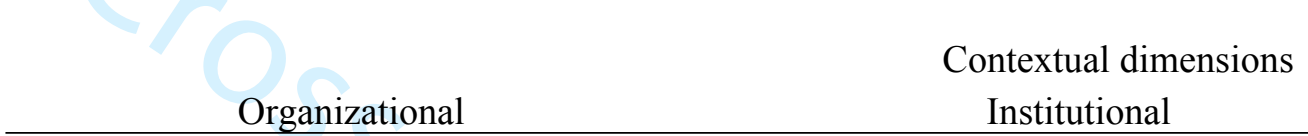

Governmental support, policy, and regulatory

Goals for asset preservation agencies

Changing practices in farming

Tacit knowledge

Technology processes

Strong intra- and inter-generational bonds

Strong community social capital

Specialized human capital

Tradition of farming sector

Inheritance laws

Cultural expectations

Business networks

Resilience during hard times
Regulations in land and inheritance law

Family lifecycles

Expectations of family succession

Changes in society/environmental concerns

Industry trends and market demands

International policy changes

Source: Wright et al. (2014), Vega Solano \& Discua Cruz (2017), Rueda \& Lambin (2013), Ponte (2002). 


\section{Excerpts from data}

"By the end of 1988 the farm was transferred to Roberto with a mandate to keep the farm in the hands of the family....He was a young man with great ambition and a desire to improve what previous generations had started. ... his main goal was to emulate his grandparents, who established the Santa Ana farm in the Antigua region in Guatemala.... " (Clara, Santa Ana)

" The changes that have taken place did not happen overnight, but over 40 years, but over time they made a huge impact on local communities and the environment....Our farm has around 750 manzanas [land measure -1 manzana $=1.75$ acres], and 200 of them have been kept as virgin jungle to maintain the micro-climate of the region, to produce the water people drink, and maintain greenery on walking trails...there are little tigers, monkeys, squirrels, pumas, agoutis, cuyusos, dantos or tapir, sloth bears, deer, mountain pigs and birds, including the quetzal.." (Heidi, Santa Gertha)

" We have just acquired more land, and our goal is to create a real coffee experience, where people can come to the local hotel we are starting now in the mountains, go for coffee trails and enjoy the mountains... we have tried hard to stop deforestation because the best coffee grows under shade of large trees, and those trees take decades to reach such height...this then changes the micro climate and we can experiment then with new strains of coffee plants; they are naturally fertilized and we can ensure that organic nutrients reach these sites... we have to do it for future generations of this community and our family..."(Lester, San Antonio)

" However, all the daughters, together with their relatives, have shown interest in the future to settle in the property of Santa Gertha. The son of the oldest daughter (grandson of the founders) is studying two careers (agriculture and journalism) ... everyone, in one way or another, will be involved in the various activities that comprise the company because there is space for everyone." (Heidi, Santa Gertha)

"Roberto wanted all employees to feel like they are part of the family. Through the payment of higher prices for our products we started to improve workers' conditions on site." (Clara, Santa Ana)

"...that initiative supported what we wanted to do in the farm...a score of $80 \%$ means a price increase of $\$ 8.00$ /quintal and a score of $90 \%$ means a price increase of $\$ 9.00$ /quintal. In its first evaluation, we received a score of $84 \%$, thereby getting an $\$ 8.00$ /quintal price increase. By engaging in this initiative supported by the large retailer in the US, all employees now enjoy benefits that are uncommon on other coffee farms in Antigua, such as a health clinic on site, dining facilities, resting quarters. (Roberto, Santa Ana)

\section{First order concepts}

Family vision for business build-up

Second order themes

Shared vision and commitment
Shared

understanding

about looking

after the

environment

Looking after the community and the environment
Complementing family objectives with future business growth

Looking after the community and workforce through a shared and aligned vision

Family intention to look after the community through business decision making 
"...we train the local community on coffee plants and how to look after its environment, I mean you have to teach that coffee is better in well-looked-after land, with plenty of trees ... that requires training and education, in that way people start to look after the plants and treat the environment for their families too... we all [family] know our family survival in producing coffee is connected to their welfare too." (Anibal, San Antonio)
Common

understanding of the importance of looking after the environment and community
"I attained a specialized agricultural engineering degree from the Pan-American Agricultural School Zamorano (in Honduras), and later pursued a specialized degree in the University of Florida (USA)....our coffee had always enjoyed great prestige due to its quality, and it was at least always possible to commercialize it. Why not do everything possible to improve the quality of the farm's product to get a better price? Why not go even further to include other factors in addition to price that could differentiate the product and make it widely known and attractive to consumers at a premium price?" (Roberto, Santa Ana)

" I mean, you have to get involved in the development of what your parents started, it is a family goal that we expand on our farm and allow other family members to be involved. I studied agricultural engineering at Zamorano (Honduras) and coffee was my passion. I learned all the knowledge my grandfather gave to my dad about how to plant coffee and they made sure I knew the secrets they had learned over the years... yet now due to the changes of weather you have to combine that knowledge with new ways of cultivating coffee... After university, I could apply modern techniques to the knowledge my family had over generations, since my grandfather, to develop good yield in our plantations and produce better coffee...I have attended every training course for coffee there is, it is really a commitment we make as a family." (Lester, San Antonio)

"One of the problems is that in Matagalpa (where Santa Gertha is located) there wasn't a university for years, so it was often the case that the next generation that came to the country as a settler, did not study, yet brought with them a tradition in farming or working ethics that was useful in blending family and business goals...The descendants of Europeans usually study in good schools in Nicaragua, and then do their undergraduate and postgraduate studies abroad." (Hans, Santa Gertha)

"Heidi speaks Spanish, English, and German, and gives international talks about community improvement topics around coffee. She has already delivered talks in Barcelona, Austria and Seattle, which is the capital of gourmet coffee, about 'women building community', and also in New York..." (Hans, Santa Gertha)

\section{Specialized knowledge in agriculture}

Family influence in the use of specialized knowledge
Combination of traditional and specialised knowledge
Traditional knowledge to complement lack of specialized knowledge

Family members disseminating information about the place where family coffee is produced 
"...You need to specialize to be in coffee farming, my son is good in coffee production yet he also relies on the commitment of the family to support the family vision... we have exported in bulk for years, but now specialty coffee requires us to go back to the roots of coffee, to know the process inside out and demonstrate that coffee is looked after, that all organic methods are used and that it can compete in taste. As the new cafe was set up we needed to show the relevance of our knowledge of this place, its soils, that we can bring out the best coffee out of it but also that family members were committed for generations to this, it is the only way you can really show you are just not growing any type of coffee.. it is our name after all that is displayed in our coffee bags, our family history is there but also we can be proud that we build on that generational knowledge with new techniques ..." (Lucia, San Antonio)

"Our farms are located between 1,240 and 1,500 meters... when coffee is at higher altitude, production occurs as in a kind of a refrigerator, so the ripening process slows down, producing a stronger and more aromatic grain; that's why they call it 'gourmet' coffee. It needs to be produced at more than 1000 metres, without chopping the peel during its process, with limited sun exposure, and then picked at the right time." (Hans, Santa Gertha)

"...you need to rely on who you know to produce good coffee; the banks are crucial for this yet we would not go to a bank to put our property as collateral unless we are certain that our harvest will be good. That is the confidence we have when we have applied all we know... the bank officials know my dad and have seen him improve his sales every year, so it was easier for me to go to the bank and ask for more funds just to expand a bit on introducing new plants and improve irrigation when needed..." (Lester, San Antonio)

"The products offered by the company have improved by technical assistance; for example, we bring non-family members, who are technicians from Germany, to help develop our products... this is done in combination with local knowledge...Many of the new products that they have were emerging because of the exclusivity of the market that visits Santa Gertha, since the majority of visitors are foreigners who have settled in the country or who are visiting from overseas; then we can talk to them in our nearby restaurant to talk and get a lot of feedback on the quality of the services, new (coffee) products, etc." (Heidi, Santa Gertha)

"..the alliance with our main customer relied on sincerity, loyalty and mutual interest. Seattle's had something that we wanted, which was price stability, because at that time the ICO agreement had expired and prices were extremely volatile. On the other hand, we also had something that our customer wanted: an extremely high-quality coffee ideal for their expansion plan." (Roberto, Santa Ana)
Specialized

knowledge in

agriculture

related to

traditional family

knowledge

Importance of

understanding the

key natural

features of a

place and product

$\begin{array}{ll}\text { Family networks } & \text { Development of } \\ \text { for support } & \begin{array}{l}\text { an exchange } \\ \text { network }\end{array}\end{array}$

Non-family networks' support for differentiation

Alliance influence on building commercial relationships 
"Alliances with large players are needed if you want your coffee to be widely known, I mean we could send samples anywhere yet we needed a stable relationship. Italians love coffee so we needed to contact a known brand. Anibal studied in Italy and he knew people there because he always took coffee samples when he returned... he was then able to contact them and ask them if they wanted to try our new blends based on estate-grown coffee... the Italians were looking to differentiate as well so it worked really well, they love what they could do with our coffee and we like that we could have a new customer, not only the US market." (Lester, San Antonio)

"...You need to compete because you can have the best coffee according to your taste, yet it is the final consumer who chooses which coffee he wants. We have to promote our coffee but unless it is out there competing and winning competitions we will be just one more coffee. That is why we enter competitions now, we know our coffee is good and we just achieved the invitation for the cup of excellence, we may not win anything but just getting our name out there in this competition is good, I also get to see what others are doing and what features international experts are looking for..." (Lester, San Antonio)

" Such an achievement was the result of improving our product, attending fairs in the past and of gaining recognition through competition to show that we are committed to our farm and our product." (Roberto, Santa Ana)

" My wife, contrary to the Latin American culture, made a deal with our daughters: 'do not ask for parties, on the contrary you can travel'; and in fact, they began to travel, which has given them a cultural, linguistic, professional, discipline, contact with others, etc. that otherwise they would not have had access to. (Hans, Santa Gertha)

\author{
Alliances' \\ influence on \\ acknowledging \\ customer \\ demands
}

\section{Alliances' influence on changing market trends}

Increased interest in international alliances and symbiotic relationships

Family objectives in building alliances 